\title{
Majalah Kesehatan Indonesia
}

Volume 2, Issue 1, April 2021, p. 9-15

P-ISSN 2745-6498, E-ISSN 2745-8008

\section{Ivermectin dan Covid-19: Sebuah Tinjauan Literatur}

\author{
Henry Wijaya ${ }^{\left.{ }^{*}\right)}$, Niluh Ayu Sri Saraswati ${ }^{2}$, Devinqa Adhimah Amanda ${ }^{3}$ \\ ${ }^{1}$ Fakultas Kedokteran Universitas Brawijaya \\ ${ }^{2}$ Fakultas Kedokteran Universitas Udayana \\ ${ }^{3}$ Fakultas Kedokteran Universitas Sumatera Utara
}

\section{ARTICLE INFO}

\section{Article history:}

Received January 29, 2021

Accepted 13 February 2021

Published 25 April 2021

\begin{tabular}{l}
\hline Keyword: \\
coVID-19 \\
Ivermectin \\
Anti-parasite \\
*) corresponding author \\
Fakultas Kedokteran Universitas Brawijaya; \\
Jl. Veteran, Ketawanggede, Kec. Lowokwaru, \\
Kota Malang, Jawa Timur 65145
\end{tabular}

Email: Henrywijaya001@gmail.com

DOI: $10.30604 /$ makein.202119

\section{A B S T R A C T}

Coronavirus disease (COVID-19) is an infectious disease that has been declared a pandemic by WHO and has become a case of a health emergency in the world. This disease is caused by the novel coronavirus (SARS-CoV-2) which was first identified in China. Until now, various studies have been conducted to find the most effective drug in eradicating this pandemic. Ivermectin, an anti-parasitic drug, is known to have antiviral properties by inhibiting the entry of viruses into the cells. On this basis, Ivermectin is believed to be capable of being one of the COVID-19 therapies. This literature review is a review of emerging cases, namely COVID-19 and its relation to Ivermectin, using the published data obtained through Google Scholar, PubMed, and WHO dataIvermectin, a parasitic agent that has been approved by the FDA, was able to prevent viral proteins from entering the host cell nucleus. Ivermectin was also shown to be able to accelerate viral clearance in the body compared to the placebo group and show a significant reduction in CRP and LDH levels. Patients receiving ivermectin also showed a lower incidence of respiratory distress and a shorter duration of hospitalization. The administration of ivermectin as a COVID-19 drug can have a positive impact on patients both clinically and in the laboratory.
ABSTRAK: Penyakit coronavirus (COVID-19) adalah suatu penyakit infeksi yang telah diumumkan sebagai suatu pandemi oleh WHO dan menjadi kasus gawat darurat kesehatan di dunia. Penyakit ini disebabkan oleh novel coronavirus (SARS-CoV-2) yang pertama kali di China. Hingga saat ini berbagai penelitian telah dijalankan untuk menemukan obat yang paling efektif dalam membasmi pandemi ini. Ivermectin, obat anti parasit, diketahui memiliki sifat anti virus dengan cara menghambat proses masuknya virus ke dalam sel tubuh. Dengan dasar ini, Ivermectin dipercayai mampu menjadi salah satu terapi COVID-19. Tinjauan literatur ini merupakan sebuah tinjauan kasus emerging yakni COVID-19 dan kaitannya dengan Ivermectin, dimana sumber tulisan didapatkan melalui data google cendekia, PubMed, dan WHO. Ivermectin, suatu agen parasit yang telah disetujui oleh FDA, mampu mencegah protein virus masuk ke dalam nukleus sel host. Ivermectin juga dibuktikan mampu mempercepat klirens virus di dalam tubuh dibandingkan dengan kelompok placebo dan menunjukkan penurunan yang signifikan pada kadar CRP dan LDH. Pasien-pasien yang mendapatkan ivermectin juga menunjukkan angka kejadian distres nafas yang lebih rendah dan durasi rawat inap yang lebih singkat. Pemberian ivermectin sebagai obat COVID-19 mampu memberikan dampak yang positif kepada pasien baik secara klinis maupun laboratorium.

This open access article is under the CC-BY-SA license. 


\section{PENDAHULUAN}

Coronavirus adalah suatu virus RNA untai positif dengan morfologi menyerupai suatu mahkota jika dilihat di bawah mikroskop elektron (Corona adalah bahasa latin untuk mahkota) karena adanya struktur glikoprotein yang meruncing di bagian amplop virus (Weiss \& Martin, 2005). Subfamili Orthocoronavirinae dari famili Coronaviridae (ordo Nidovirales) diklasifikasikan menjadi 4 genus $\mathrm{CoV}$ (Coronavirus): Alphacoronavirus (alphaCoV), Betacoronavirus (betaCoV), Deltacoronavirus (deltaCoV), dan Gamma coronavirus (gamma CoV) (Singhai, 2020). Lebih lagi, genus betaCoV dibagi kembali menjadi 5 sub genus. Karakterisasi genomik telah menunjukkan bahwa kemungkinan kelelawar dan hewan pengerat adalah sumber gen dari alphaCoV dan betaCoV. Sebaliknya, spesies unggas tampaknya merupakan sumber gen dari deltaCoV dan gammaCoV (Cascella et al. 2020).

Anggota dari famili virus ini dapat menyebabkan penyakit-penyakit di bidang respirasi, pencernaan, hepar, bahkan hingga neurologis pada berbagai spesies hewan yang meliputi unta, lembu, kucing, dan kelelawar. Hingga saat ini, tujuh Human CoronaVirus (HCoVs) yang mampu menginfeksi manusia telah teridentifikasi. Beberapa HCoVs bahkan sudah diidentifikasi pada pertengahan tahun 1960 , sementara yang lainnya baru terdeteksi beberapa tahun yang lalu (Cascella et al. 2020).

Saat ini berbagai obat telah diuji coba efektivitasnya terhadap COVID-19 dengan hasil yang bervariasi. Pada kesempatan kali ini, penulis akan merangkum beberapa terapi yang digunakan saat ini dan secara spesifik membahas ivermectin sebagai obat anti parasit yang memiliki sifat antivirus terhadap COVID-19. Tujuan penulisan tinjauan literatur ini adalah untuk memberikan wawasan terhadap peran Ivermectin sebagai terapi infeksi COVID-19.

\section{METODE}

Kami melakukan peninjauan literatur-literatur yang berada di tiga database: Ovid, Scopus, dan Pubmed. Kami mencari literatur mulai dari tanggal 1 Desember 2019 hingga 20 Januari 2021. Selain itu, daftar referensi dari masingmasing literatur juga kami telusuri untuk peninjauan. Literatur yang sama akan dikeluarkan dari peninjauan. Daftar judul yang sudah ada akan ditinjau oleh 2 peneliti (D.A dan N.A). Artikel akan diskrining berdasarkan kriteria inklusi. Setelah data final didapatkan, maka artikel yang ada akan dibuat menjadi suatu tinjauan literatur

Artikel yang dipilih adalah artikel yang menggunakan obat ivermectin sebagia obat utama pada pasien-pasien COVID-19 baik derajat ringan, sedang, maupun berat. Artikel-artikel yang tidak menggunakan ivermectin sebagai pembanding utama atau variabel utama akan dieksklusikan dari tinjauan literatur.

Tinjauan literatur ini merupakan sebuah tinjauan kasus emerging yakni COVID-19 dan salah satu obat anti parasit yaitu ivermectin, dimana sumber literatur didapatkan melalui data google cendekia, PubMed, dan WHO, menggunakan kata kunci: COVID-19 dan Ivermectin. Datadata yang didapatkan kemudian dievaluasi kembali dan disusun menjadi sebuah bentuk tulisan ulasan.

\section{HASIL DAN PEMBAHASAN}

Berdasarkan World Health Organization (WHO), penyakit akibat infeksi virus terus bermunculan dan menjadi suatu masalah yang serius bagi kesehatan masyarakat. Dalam dua puluh tahun terakhir, beberapa epidemi virus seperti Severe Acute Respiratory Syndrome CoronaVirus (SARS-CoV) dari tahun 2002 hingga 2003 dan H1N1 influenza pada tahun 2009 telah dilalui. Yang terbaru, the Middle East Respiratory Syndrome coronavirus (MERS-CoV) pertama kali teridentifikasi di Saudi Arabia pada tahun 2012 (Cascella et al. 2020).

Hingga hari ini, suatu epidemi kasus dengan penyakit infeksi saluran nafas bawah yang tidak dapat dijelaskan terdeteksi di daerah Wuhan, area metropolitan terbesar di provinsi Hubei, China. Kasus ini pertama kali dilaporkan ke kantor WHO di China pada 31 Desember 2019 (Li et al, 2020; Donde et al, 2021). Berbagai literatur telah berhasil melacak sumber (individu) yang pertama kali mengalami infeksi coronavirus dan membahas tentang gejala yang dialaminya. Namun, mereka tidak mampu mengidentifikasi agen kausatifnya, maka dari itu kluster kasus pertama ini (berjumlah 29 orang) diklasifikasikan sebagai "pneumonia of unknown etiology". Center for Disease Control China dan CDC lokal di provinsi China melakukan program investigasi wabah ini secara intensif hingga akhirnya, etiology infeksi saluran pernafasan bawah ini dapat dikenali sebagai virus dari famili coronavirus (Cascella et al. 2020).

\section{Terapi COVID-19 hingga saat ini}

Tidak ada terapi antivirus spesifik yang direkomendasikan untuk COVID-19. Terapi yang dilakukan bersifat simptomatis dan terapi oksigen merupakan langkah awal dalam mengatasi gangguan pernafasan atau ventilasi yang terjadi pada pasien. Non-invasive (NIV) dan Invasive Mechanical Ventilation (IMV) mungkin diperlukan pada kasus-kasus gagal nafas yang tidak membaik dengan terapi oksigen saja. Perlu diperhatikan bahwa pasien-pasien dengan komorbid atau komplikasi perlu mendapatkan perawatan di ruang intensif. (Cascella et al. 2020). Hingga saat ini, berbagai macam obat telah diteliti efektifitas untuk melawan infeksi coronavirus. Beberapa diantaranya adalah obat-obatan yang sudah sering digunakan untuk penyakit lain. Klorokuin, hidroksiklorokuin, azithromycin, remdesivir, dan yang tidak kalah penting adalah obat anti parasit, ivermectin (Ali et al. 2020).

\section{Terapi Oksigen}

Kisaran target saturasi oksigen pada pasien-pasien dengan COVID-19 direkomendasikan pada angka 92-96\%. Penggunaan oksigen tambahan pada orang dewasa dengan COVID-19 belum divalidasi dan disetujui secara resmi, tetapi bukti-bukti tidak langsung dari beberapa kondisi kritis lainnya menyatakan bahwa target oksigen yang optimal adalah antara 92\% dan 96\%. Bukti-bukti tidak langsung tersebut berasal dari dua penelitian di bawah ini: (Shenoy et al. 2020)

Pertama, sebuah meta-analisis yang mencakup 25 penelitian acak terkontrol terhadap 16.037 pasien-pasien dengan penyakit akut. Penelitian tersebut menyimpulkan bahwa pemberian oksigen secara liberal (median 96\%, dengan kisaran 94-99\%) berkaitan dengan bertambahnya mortalitas (risiko relatif $1.21,95 \%$ interval kepercayaan 1.03 1.43) ketika dibandingkan dengan terapi oksigen yang lebih konservatif (Chu et al. 2018)

Kedua, Penelitian LOCO-2 dimana pasien-pasien Acute Respiratory Distress Syndrome (ARDS) dirandomisasi ke dalam kelompok konservatif (target tekanan parsial oksigen [PaO2] sebesar 55 - $70 \mathrm{mmHg}$; saturasi oksigen yang dinilai dengan pulse oksimenter [SpO2] sebesar 88-92\%) vs kelompok liberal (PaO2 target sebesar 90 - 105mmHg; SpO2 
lebih besar sama dengan 96\%). Penelitian tersebut dihentikan karena pada kelompok terapi konservatif mengalami peningkatan kematian. Pada hari ke-90, 44.4\% dari pasien di kelompok pemberian oksigen konservatif dan $30.4 \%$ pada kelompok pemberian oksigen secara liberal meninggal (perbedaan, 14 persen; 95\% interval kepercayaan, 0.7 - 27.2) (Shenoy et al. 2020).

\section{Kortikosteroid}

Peran kortikosteroid pada pasien-pasien non-COVID dengan ARDS masih kontroversial (Singh et al. 2020). Diantara strategi terapeutik lainnya, walaupun terapi kortikosteroid sistemik untuk pneumonia virus atau ARDS tidaklah direkomendasikan (Wang et al. 2020; Shenoy et al. 2020) Pada kasus Covid-19 induced ARDS (CARDS) obatobatan ini umumnya digunakan (cth.., metilprednisolon $1 \mathrm{mg} / \mathrm{kg} /$ hari). Perlu diperhatikan, penelitian acak terkontrol terbaru yang berskala besar (penelitian RECOVERY) menunjukkan bahwa deksametason menurunkan mortalitas sebesar 1/3 pada pasien-pasien COVID-19 yang sakit kritis. Meta analisis yang dilakukan oleh Satgas (Satuan Tugas) COVID-19 WHO yang meliputi 1703 pasien (1007 pasien berasal dari penelitian TRIAL), mengkonfirmasi temuan berkurangnya mortalitas pada hari ke-28 dengan pemberian deksametason (OR 0.66, 95\% interval kepercayaan 0.53 0.82). Meskipun beberapa temuan telah mengkonfirmasi manfaat kortikosteorid pada pasien-pasien yang sakit kritis akibat infeksi COVID-19, beberapa pertanyaan masih belum terjawab dan pantas dijadikan bahan diskusi serta diteliti lebih lanjut di masa yang akan datang (Matthay \& Thompson, 2020).

Penelitian acak terkontrol lainnya dilakukan di Spanyol pada tahun 2018 yang melibatkan 17 unit ruangan intensif. Penelitian ini meneliti peran dari deksametason pada pasienpasien dengan diagnosis ARDS baik yang disebabkan oleh infeksi COVID-19 maupun penyebab lainnya. Sejumlah 277 pasien diikutsertakan dalam penelitian dan 139 di antaranya dirandomisasi ke dalam kelompok deksametason, sementara sisanya adalah kelompok kontrol. Rata-rata durasi bebas ventilasi (pada hari ke-28) adalah lebih tinggi pada kelompok deksametason dibandingkan dengan kelompok kontrol (12.3 hari vs 7.5 hari, $\mathrm{p}<0.0001$ ), dengan penurunan mortalitas-akibat-segala-penyebab sebesar $15.3 \%$ pada hari ke-60 (21\% vs 36\%, p = 0.005), penurunan sebesar $12.5 \%$ pada mortalitas di ICU (19\% vs $31 \%, \mathrm{p}=0.017$ ) dan penurunan sebesar $12.5 \%$ pada mortalitas di rumah sakit ( $24 \%$ vs $36 \%$, p $=0.024)$ (Singh et al. 2020).

\section{Anti virus}

Mayoritas pasien-pasien dengan COVID-19 akan sembuh dengan sendirinya tanpa memerlukan terapi, sehingga pada mayoritas kasus, pemberian terapi antivirus adalah hal yang tidak wajib. Namun, menunggu pasien jatuh dalam kondisi yang berat sebelum memulai terapi dapat menyebabkan hilangnya kesempatan memberikan terapi pada fase awal penyakit, yaitu fase dimana replikasi virus masih dapat dikendalikan. (Yavuz \& Ünal, 2020; Ahidjo et al. 2020). Beberapa modalitas anti-virus saat ini sedang diteliti untuk melawan SARS-CoV-2 dan hingga saat ini sudah ada 400 penelitian klinis yang sedang berlangsung di clinicaltrials.gov (Ahidjo et al. 2020). Obat yang paling umum digunakan adalah golongan inhibitor RNA polymerase (remdesivir dan favipavir) dan inhibitor sintesis protein virus (lopinavir/ritonavir) (Yavuz \& Ünal, 2020).

\section{Obat-obatan imunomodulator}

Obat-obatan imunomodulator yang banyak diteliti adalah klorokuin yang bekerja sebagai inhibitor entri virus ke dalam sel, saat ini sedang ada 43 penelitian berlangsung di ClinicalTrials.gov. Klorokuin adalah derivat dari kuinin yang telah digunakan secara luas selama beberapa dekade untuk terapi dan profilaksis terhadap malaria. Selain dari sifat anti-malarianya, klorokuin juga menunjukkan aktivitas antivirusnya terhadap berbagai jenis virus seperti virus dengue (Farias et al. 2014), virus zika, (Delvecchio et al. 2016), virus chikungunya (Khan et al. 2010), dan virus influenza. Klorokuin juga telah dibuktikan secara invitro sebagai antivirus yang efektif terhadap SARS-COV baik sebelum induksi infeksi maupun setelah terjadinya infeksi (Ahidjo et al. 2020; Li et al, 2020).

Salah satu mekanisme kerja obat-obatan imunomodulasi adalah dengan cara mengurangi produksi sitokin. Baik klorokuin dan hidroksiklorokuin memiliki beberapa sifat yang mampu mencegah infeksi SARS-CoV-2 dan juga menghambat perburukkan penyakit. Obat-obatan tersebut menghambat masuknya virus ke dalam sel. Coronavirus membajak reseptor ACE2 agar bisa masuk ke dalam sel. Receptor Binding Domain (RBD) SARS-CoV-2 memiliki afinitas yang lebih tinggi (15-lipat) untuk berikatan dengan ACE2 dibandingkan dengan SARS-CoV RBD, menyebabkan sifat inefektivitas yang lebih tinggi. Kedua obat tersebut dibuktikan mampu menghambat glikosilasi ACE2. Hal ini dapat mengganggu aktivitas virus dalam berbagai cara. Proses fusi virus dalam sel host dan replikasi dapat dicegah. Dalam sel-sel yang memproses antigen, obat-obatan dapat mencegah pemrosesan antigen dan presentasi antigen yang dimediasi oleh MHC kelas II. Pada akhirnya efek ini dapat mencegah aktivasi sel T, ekspresi CD 154, dan menurunkan produksi sitokin (Khuroo, 2020; Sebastián et al. 2020).

\section{Antibiotik}

Informasi terhadap terapi antimikroba yang diberikan pada pasien-pasien dengan infeksi SARS-CoV-2 masih langka. Walaupun penggunaan antibiotik telah dilaporkan pada beberapa penelitian, namun penggunaannya masih belum mendapatkan rekomendasi yang cukup karena ada kemungkinan antibiotik-antibiotik tersebut dapat digunakan secara tidak benar atau tidak tepat sasaran, khususnya ketika dokter meresepkan antibiotik-antibiotik berspektrum luas (Carla et al. 2020). Salah satu penelitian dari China hanya melaporkan satu kasus dari 99 pasien yang mengalami koinfeksi dengan bakteri (Elske et al.2020). Penelitian lain dari China bahkan melaporkan tidak adanya ko-infeksi bakteri pada 201 pasien rawat inap dengan COVID-19, yang 74\% diantaranya memiliki hasil kultur (Chaomin et al. 2020). Salah satu penelitian dari Amerika Serikat melaporkan tidak adanya patogen atipikal dari 115 pasien yang terdiagnosis dengan community-acquired COVID-19 (David et al. 2020).

Azithromycin merupakan salah satu jenis antibiotik yang sering diteliti penggunaannya untuk pasien-pasien dengan infeksi COVID-19. Bleyzac (2020) percaya bahwa antibiotik golongan makrolida, azithromycin, memiliki profil yang spesial dan menarik terkait kegunaannya dalam infeksi COVID-19. Selain itu Azithromycin juga dipercayai memiliki efek antiviral sinergis terhadap SARS-CoV-2 ketika digabungkan dengan HCQ baik secara in vitro maupun secara klinis. Azithromycin tampaknya menurunkan entri virus ke dalam sel. Selain itu, obat ini juga meningkatkan respons imun terhadap virus dengan beberapa mekanisme. Azithromycin meningkatkan produksi interferon tipe I dan tipe III (terutama interferon- $\beta$ dan interferon- $\lambda$ ), dan gen-gen yang terlibat dalam pengenalan virus seperti MDA5 dan RIGI. Mekanisme-mekanisme ini secara universal terlibat dalam respons tubuh terhadap agen infeksius, dan kemungkinan terhadap SARS-CoV-2 (Bleyzac et al. 2020).

\section{Ivermectin sebagai terapi COVID-19}


Ivermectin telah digunakan selama beberapa tahun sebagai terapi untuk berbagai penyakit infeksius pada mamalia. Obat ini memiliki profil keamanan yang baik dengan efek samping yang rendah ketika diberikan melalui mulut. Ivermectin diidentifikasi pada akhir tahun 1970an dan pertama kali disetujui untuk penggunaannya pada hewan di tahun 1981. Potensi kegunaannya pada manusia disetujui beberapa tahun kemudian. Selanjutnya, William C. Campbell dan Satoshi Omura yang menemukan dan mengembangkan obat ini mendapatkan penghargaan nobel di bidang fisiologi atau kedokteran pada tahun 2015 (Heidary \& Gharebaghi, 2020).

Penelitian-penelitian telah menunjukkan bahwa ivermectin adalah obat spektrum luas dengan kelarutan lipid yang tinggi dan memiliki beberapa efek terhadap parasit (Crump \& Omura, 2011; Cange et al, 2007), nematoda, arthropod, flavivirus, mycobacteria, dan mamalia melalui beberapa mekanisme (Karim et al. 2020). Selain memiliki efek anti-parasit dan anti-virus, obat ini juga memiliki efek imunomodulasi pada host. Penelitian-penelitian telah menunjukkan efeknya dalam menghambat proliferasi sel-sel kanker, dna juga meregulasi glukosa dan kolesterol pada hewan. Terlepas dari banyaknya efek dari obat-obatan ini, banyak dari mekanisme-mekanisme dasar ini masih belum diketahui. Perlu diingat, bahwa efek-efek tersebut mungkin disebabkan karena efek toksik terhadap sel (Heidary \& Gharebaghi, 2020).

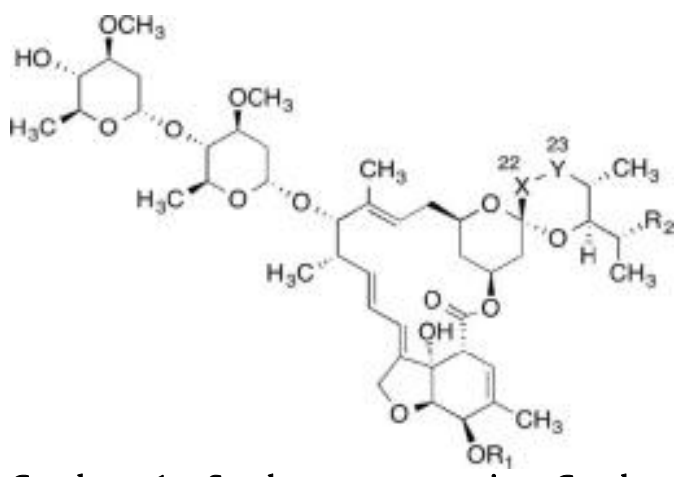

Gambar 1. Struktur avermectin. Gambar molekuler struktur avermectin, yang kemudian menjalani perubahan kimiawi sehingga membentuk ivermectin (Heidary \& Gharebaghi, 2020).

Dalam penelitian in vitro terbaru, sel-sel Vero/ (human signalling lymphocyte-activation molecule) hSLAM diinokulasi dengan virus SARS-CoV-2 atau COVID-19 diberikan $5 \mu \mathrm{M}$ ivermectin dalam 48 jam, dan hasilnya ditemukan penurunan sebesar 5000 kali lipat dalam jumlah virus RNA dibandingkan dengan kelompok kontrol (Heidary \& Gharebaghi, 2020). Penelitian ini juga menunjukkan bahwa ivermectin secara efektif membunuh hampir seluruh partikel virus dalam kurun waktu 48 jam. Penelitian ini adalah penelitian pertama yang menilai efek antivirus ivermectin terhadap COVID-19. Ivermectin diduga memiliki efek

antivirus dengan cara menghambat kerja reseptor Importin (IMP) $\alpha / \beta$, yang berperan dalam transmisi protein virus kedalam nukleus sel host. Penelitian ini juga menyarankan perlunya penelitian pada manusia untuk mengkonfirmasi manfaat ivermectin sebagai terapi COVID19 (Caly et al. 2020) Ivermectin sendiri telah dibuktikan memiliki efek antivirus dan telah diteliti manfaatnya terhadap virus-virus lainnya seperti virus zika (Barrows et al. 2020), virus dengue, yellow fever virus, west nile virus, hendra virus (Chowdury et al. 2020), dan lain sebagainya (Heidary \& Gharebaghi. 2020).

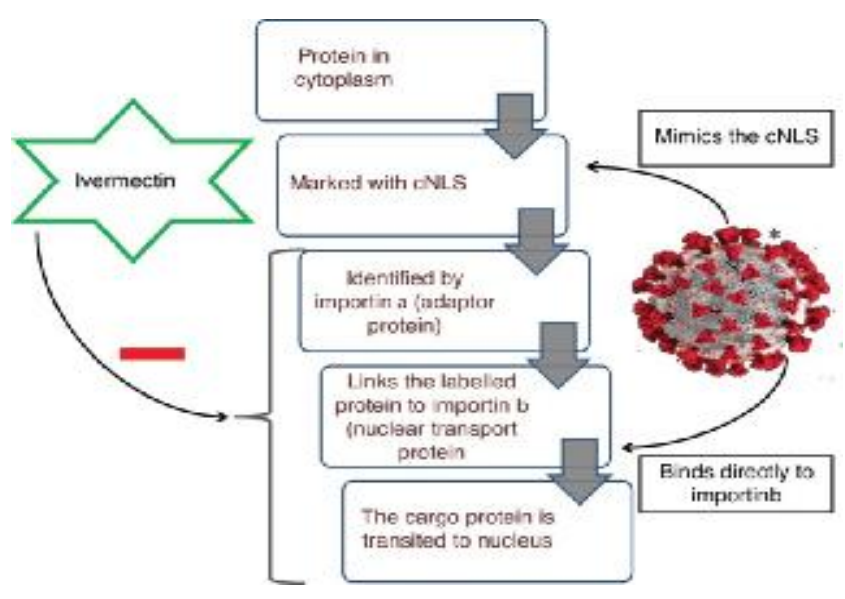

Gambar 2. Mekanisme ivermectin mencegah ikatan virus. Ivermectin menghambat transpor protein korona virus yang dimediasi oleh importin $\alpha / \beta$. cNLS: classical Nuclear Localization Signal (Dhyuti et al. 2020)

Ivermectin, suatu agen parasit yang telah disetujui oleh FDA, mampu mencegah protein virus masuk ke dalam nukleus sel host. Penelitian oleh Ahmed (2020) membandingkan ivermectin saja (12mg sekali hari selama 5 hari) atau dikombinasikan dengan doksisiklin (12mg ivermectin dosis tunggal dan $200 \mathrm{mg}$ doksisiklin di hari-1 diikuti dengan $100 \mathrm{mg}$ setiap $12 \mathrm{jam}$ selama 4 hari) dibandingkan dengan plasebo pada 72 pasien rawat inap yang di Dhaka, Bangladesh. Hasilnya adalah pemberian ivermectin selama 5 hari menyebabkan klirens virus yang lebih awal dibandingkan dengan placebo $(\mathrm{p}=0.005)$ sehingga menyatakan bahwa intervensi awal dengan obatobatan ini mungkin menghambat replikasi virus di dalam host. Pada hari ke-5 ivermectin juga menunjukkan penurunan yang signifikan pada kadar CRP dan LDH (penanda/ marker keparahan penyakit) pada hari ke-7 (Ahmed et al. 2020).

Chowdury (2020) melakukan penelitian dengan membandingkan dua kelompok: Ivermectin $200 \mu \mathrm{gm} / \mathrm{kg}$ dosis tunggal + Doksisiklin $100 \mathrm{mg} 2 \mathrm{x}$ sehari selama 10 hari di kelompok A dan hidroksiklorokuin 400mg pada hari pertama, kemudian 200mg selama 2 hari selama 9 hari dan azithromycin $500 \mathrm{mg}$ setiap hari selama 5 hari pada kelompok B. PCR untuk SARS-CoV-2 diulang pada seluruh pasien untuk mengkonfirmasi efektivitas obat. Waktu hingga pasien mencapai hasil PCR yang negatif dan waktu hingga pemulihan total dinilai untuk masing-masing kelompok (Chowdury et al. 2020).

Hasilnya adalah seluruh subjek di kelompok IvermectinDoksisiklin (kelompok A) mencapai PCR negatif untuk SARSCoV-2 setelah 8.93 hari, dan seluruhnya mencapai pemulihan simptomatis dalam waktu rata-rata 5.93 hari, dimana $55,10 \%$ sudah tidak memiliki gejala pada hari ke-5. Pada kelompok Hidroksiklorokuin-Azithromycin (kelompok B), 96.36\% menunjukkan hasil PCR negatif dengan waktu rata-rata 6.99 hari dan bebas gejala rata-rata pada hari ke9.33. Pasien-pasien kelompok A memiliki gejala yang dapat disebabkan karena pengobatannya pada $31.67 \%$ pasien, meliputi letargi pada 14 pasien (23,3\%), nausea pada 11 (18.3\%), dan vertigo pada 7 pasien (11.66\%). Pada kelompok B, 46,43\% memiliki gejala yang dapat disebabkan karena obat-obatan, meliputi 13 pasien (23.21\%) dengan pandangan kabur dan nyeri kepala; 22 (39.2\%) dengan bertambahnya 
letargi dan rasa pusing, $10(17.85 \%)$ pasien terkadang mengalami palpitasi dan 9 (16.07\%) mengalami mual dan muntah. Pada akhirnya disimpulkan bahwa kombinasi Ivermectin-Doksisiklin menunjukkan tren yang lebih superior dibandingkan dengan terapi kombinasi Hidroksiklorokuin-Azithromycin pada pasien-pasien dengan COVID-19 ringan dan moderate, walaupun perbedaan dalam waktu mencapai kondisi bebas gejala dan perbedaan waktu hingga hasil PCR adalah negatif tidak signifikan secara statistik (Chowdury et al. 2020).

Penelitian di Mymengsingh Medical College Hospital, Bangladesh menemukan bahwa dari 115 subjek yang mendapatkan $12 \mathrm{mg}$ dosis tunggal ivermectin, kejadian pneumonia, dan stroke iskemik jauh lebih rendah dibandingkan dengan 133 pada kelompok kontrol. Lebih lagi, pasien-pasien pada kelompok ivermectin memiliki jumlah yang lebih rendah dalam hal kejadian distres nafas (2.6 versus $15.8 \%$ ), atau keperluan akan oksigen (9.6 vs $45.9 \%$ ), antibiotik (15.7 versus $60.2 \%$ ) atau manajemen di ruang intensif (0.09 versus $8.3 \%$ ) (Khan et al. 2020). Pasien-pasien yang diterapi dengan ivermectin juga lebih cepat dalam mencapai kondisi virus negatif (median 4 hari dibandingkan dengan 15 hari), durasi rawat inap di rumah sakit (median 9 versus 15 hari), dan mortalitas ( 0.9 vs $6.8 \%$ ). Walaupun terapi kombinasi juga digunakan, hasil dari 196 pasien di Broward Health Medical Center (Florida, Amerika Serikat) menunjukkan penurunan yang bermakna dalam mortalitas (13.3\%) di subjek-subjek yang mendapatkan $0.2 \mathrm{mg} / \mathrm{kg}$ ivermectin (dosis kedua opsional diberikan 8 hari kemudian), dibandingkan dengan $24.5 \%$ mortalitas pada mereka yang tidak mendapatkan ivermectin (Ratjer et al. 2021).

Tabel 1

Penelitian pemberian ivermectin pada pasien dengan infeksi COVID-19

\begin{tabular}{|c|c|c|c|c|}
\hline No & Peneliti, tahun & Jenis penelitian & Jumlah sampel & Hasil Penelitian \\
\hline 1 & Ahmed et al, 2021 & $\begin{array}{l}\text { Penelitian acak, } \\
\text { tersamar-ganda, } \\
\text { terkontrol-plasebo } \\
\text { untuk menentukan } \\
\text { kecepatan } \\
\text { pemulihan dan } \\
\text { klirens virus }\end{array}$ & $\begin{array}{l}72 \text { pasien di } \\
\text { Dhaka, Bangladesh }\end{array}$ & $\begin{array}{l}\text { Pasien dikelompokkan menjadi kelompok ivermectin } \\
\text { saja (12 mg/hari) selama } 5 \text { hari, ivermectin dan } \\
\text { doksisiklin ( } 12 \mathrm{mg} \text { ivermectin dosis tunggal dan } \\
\text { doksisiklin } 100 \mathrm{mg} 2 \mathrm{x} / \text { hari selama } 4 \text { hari } \\
\text { selanjutnya), dan kelompok plasebo. } \\
\text { Kelompok perlakuan yang mendapatkan ivermectin } \\
\text { memiliki waktu yang lebih singkat hingga pemulihan } \\
\text { dan klirens virus yang lebih baik }\end{array}$ \\
\hline 2 & Ratjer et al, 2020 & $\begin{array}{l}\text { Penelitian kohort } \\
\text { dari 15 Maret } 2020 \\
\text { hingga 11 May } 2020\end{array}$ & $\begin{array}{l}280 \text { pasien, } 173 \\
\text { pasien } \\
\text { diantaranya } \\
\text { diterapi dengan } \\
\text { ivermectin }\end{array}$ & $\begin{array}{l}\text { Pasien dikelompokkan menjadi } 2 \text { kelompok } \\
\text { (kelompok yang mendapatkan ivermectin dan } \\
\text { kelompok yang tidak mendapatkan ivermectin). } \\
\text { Mortalitas secara keseluruhan lebih rendah pada } \\
\text { kelompok ivermectin }(15 \% \text { vs } 25 \%)\end{array}$ \\
\hline 3 & 2020 & $\begin{array}{lr}\text { Penelitian } & \text { kohort } \\
\text { prospektif } & \text { bulan } \\
\text { April 2020 } & \text { hingga } \\
\text { mei } 2020 & \end{array}$ & $\begin{array}{l}87 \text { pasien, } \\
\text { pasien } \\
\text { diantaranya } \\
\text { diberikan } \\
\text { ivermectin }\end{array}$ & $\begin{array}{l}\text { Seluruh pasien dalam kelompok ivermectin } \\
\text { dinyatakan sembuh dan didapati } 2 \text { kematian pada } \\
\text { kelompok kontrol. } \\
\text { Durasi rawat inap juga lebih rendah pada kelompok } \\
\text { ivermectin ( } 7.62 \pm 2.75 \text { versus } 13.22 \pm 5.90 \text { hari } \\
\text { p=0.00005) }\end{array}$ \\
\hline 4 & $a l, 2020$ & $\begin{array}{l}\text { Penelitian } \\
\text { terkontrol dari Juli } \\
2020 \quad \text { hingga } \\
\text { September } 2020\end{array}$ & 140 pasien & $\begin{array}{l}\text { Tujuh puluh pasien dalam kelompok terapi } \\
\text { (ivermectin 200mcg/kg per hari selama } 2-3 \text { hari dan } \\
\text { doksisiklin 2x per hari selama } 5-10 \text { hari) dan } 70 \\
\text { pasien kelompok terapi standar } \\
\text { Kelompok terapi ivermectin dengan doksisiklin } \\
\text { mempersingkat waktu pemulihan dan menurunkan } \\
\text { mortalitas dari } 22.72 \% \text { menjadi } 0 \% \text { pada pasien } \\
\text { dengan penyakit berat }\end{array}$ \\
\hline 5. & Alam et al, 2020 & $\begin{array}{l}\text { Penelitian } \\
\text { kasus } \\
\text { sectional) }\end{array}$ & $\begin{array}{l}100 \quad \text { pasien } \\
\text { diseleksi dengan } \\
\text { kriteria inklusi dan } \\
\text { eksklusi }\end{array}$ & $\begin{array}{l}\text { Kombinasi ivermectin dan doksisiklin dibuktikan } \\
\text { sangat efektif dalam membersihkan virus dari } \\
\text { tubuh pada pasien COVID-19 derajat ringan dan } \\
\text { sedang }\end{array}$ \\
\hline
\end{tabular}

Dalam dua laporan penelitian retrospektif pre-publikasi yang menilai luaran pada pasien-pasien yang dirawat inap dengan COVID-19, beberapa diantaranya mendapatkan terapi ivermectin. Ratjer et al melaporkan bahwa, dalam analisis univariat, mortalitas pada 173 pasien yang mendapatkan satu atau lebih dosis ivermectin adalah secara yang tidak diterapi dengan ivermectin (15\% vs $25.2 \%, \mathrm{p}=$ 0.03 ); setelah penyesuaian multivariat untuk kovariat yang bersangkutan, perbedaan mortalitas dapat dikonfirmasi hasilnya dengan OR 0.21, p = 0.03; HR 0.37, p = 0.03) (Ratjer et al. 2021). Gorial et al meneliti waktu rata-rata durasi rawat inap pasien yang mendapatkan ivermectin $(200 \mu \mathrm{g} / \mathrm{kg})$ dan yang tidak sebagai terapi tambahan dengan hidroksiklorokuin/ azithromycin. Enam belas pasien yang mendapatkan ivermectin menjalani rawat inap dengan ratarata 7.62 hari, jauh lebih rendah dibandingkan dengan ratarata durasi rawat inap 71 pasien yang tidak mendapatkan ivermectin (13.22 hari; $\mathrm{p}=0.00005)$. Dua pasien meninggal dalam kelompok kontrol sedangkan tidak ada mortalitas pada kelompok ivermectin (Gorial et al. 2020).

Penelitian mengenai penggunaan Ivermectin beserta obat-obatan lainnya dalam menangani wabah COVID-19 masih terus berlangsung. Terlepas dari hasil yang memuaskan pada beberapa penelitian baik secara in vitro maupun in vivo, penggunaan ivermectin masih akan terus diteliti untuk meningkatkan akurasi dari penelitianpenelitian yang ada sebelumnya. Berikut adalah beberapa penelitian yang sedang berlangsung terkait penggunaan ivermectin untuk terapi pasien-pasien dengan infeksi COVID-19. signifikan lebih rendah dibandingkan dengan 107 pasien 
Tabel 2

Daftar penelitian berlangsung untuk pemberian ivermectin pada pasien dengan COVID-19 (Jans \& Wagstaff, 2020)

\begin{tabular}{|c|c|c|c|c|}
\hline No & Judul penelitian, Identifier Clinical Trials & $\begin{array}{l}\text { Jumlah } \\
\text { sampel }\end{array}$ & Intervensi & Waktu dimulai \\
\hline 1 & $\begin{array}{l}\text { Efek ivermectin terhadap replikasi SARS-CoV-2 } \\
\text { pada pasien-pasien dengan COVID-19, } \\
\text { NCT04381884 }\end{array}$ & 45 & $\begin{array}{l}\text { Ivermectin } 0.6 \mathrm{mg} / \mathrm{Kg} \text { per hari dengan } \\
\text { pelayanan standar vs pelayanan } \\
\text { standar saja }\end{array}$ & 18 Mei 2020 \\
\hline 2. & $\begin{array}{l}\text { Kombinasi Ivermectin dan nitazoxanide } \\
\text { Ivermectin untuk COVID-19, } \underline{\text { NCT04360356 }}\end{array}$ & 100 & $\begin{array}{l}\text { Ivermectin } 0.2 \mathrm{mg} / \mathrm{kg} \text { sekali ditambah } \\
\mathrm{NZX} 500 \mathrm{mg} 2 \mathrm{x} / \text { hari selama } 6 \text { hari } \\
\text { versus pelayanan standar }\end{array}$ & 20 Mei 2020 \\
\hline 3 & $\begin{array}{l}\text { Ivermectin vs Placebo untuk terapi pasien- } \\
\text { pasien dengan COVID-19 ringan hingga } \\
\text { moderate, NCT04429711 }\end{array}$ & 100 & Ivermectin $12-15 \mathrm{mg} /$ hari vs kontrol & 12 Mei 2020 \\
\hline 4 & $\begin{array}{l}\text { Hidroksiklorokuin dan Ivermectin untuk terapi } \\
\text { infeksi COVID 19, NCT04391127 }\end{array}$ & 100 & $\begin{array}{l}\text { Ivermectin } 12 \mathrm{mg}(<80 \mathrm{~kg}) \text { dan } 15 \mathrm{mg} \\
\text { (>80kg) sekali vs HCQ } 400 \mathrm{mg} 2 \mathrm{x} / \mathrm{hari} \\
\text { selama } 1 \text { hari kemudian } 200 \mathrm{mg} / \text { hari } \\
\text { selama } 4 \text { hari vs plasebo }\end{array}$ & 4 Mei 2020 \\
\hline 5 & $\begin{array}{l}\text { Efikasi Ivermectin pada pasien-pasien dewasa } \\
\text { di tahap awal Covid-19, NCT04405843 }\end{array}$ & 400 & $\begin{array}{l}\text { Ivermectin } 0.3 \mathrm{mg} / \mathrm{kg} \text { selama } 5 \text { hari vs } \\
\text { placebo }\end{array}$ & 20 Juni 2020 \\
\hline
\end{tabular}

\section{KESIMPULAN DAN SARAN}

Penyakit akibat infeksi Coronavirus tahun 2019 (COVID19) yang berasal dari kota Wuhan, Provinsi Hubei, China bagian tengah, telah menyebar secara cepat hingga ke lebih dari 72 negara. . Hingga saat ini, belum ada prediksi kapan penyebaran virus ini akan berhenti atau berakhir. Sebagai infeksi virus, proses penyembuhan pasien sangat bergantung pada respons imun tubuh dalam mengatasi infeksi. Obatobatan yang digunakan hanya bersifat membantu. Belakangan ini, ivermectin, suatu obat golongan anti-parasit dibuktikan mampu menghambat proses replikasi virus melalui beberapa tahap. Beberapa penelitian juga telah

\section{DAFTAR PUSTAKA}

Ahidjo, B. A., Loe, M. W., Ng, Y. L., Mok, C. K., \& Chu, J. J. (2020). Current Perspective of Antiviral Strategies against COVID19. ACS Infect Dis, acsinfecdis.0c00236. doi: 10.1021 /acsinfecdis.0c00236

Ali, M. J., Hanif, M., Haider, M. A., Ahmed, M. U., Sundas, F., Hirani, A.,Karim, A. H. (2020). Treatment Options for COVID-19: A Review. Front Med (Lausanne), 7: 480. doi: $10.3389 /$ fmed.2020.00480

Alam, M. T., Murshed, R., Bhiuyan, E., Saber, S., Alam, R. F., \& Robin, R. C. (2020). A Case Series of 100 COVID-19 Positive Patients Treated with Combination of Ivermectin and Doxycycline. Journal of Bangladesh College of Physicians and Surgeons, 38(July), 10-15. doi: 10.3329/jbcps.v38i0.47512

Ahmed, S., Mahbubul, M., Ross, A. G., Sharif, M., Clemens, J. D., Kibtiya, M., Swe, C., Zaman, K., Somani, J., \& Yasmin, R. (2020). A five-day course of ivermectin for the treatment of COVID-19 may reduce the duration of illness. International Journal of Infectious Disease, 103(January), 214-216. doi: 10.1016/j.ijid.2020.11.191

Barrows, N. J., Campos, R. K., Powell, S. T., Prasanth, K. R., SchottLerner, G., Soto-Acosta, R. (2016). A Screen of FDAApproved Drugs for Inhibitors of Zika Virus Infection. Cell Host and Microbe, 20(2), 259-270. doi: 10.1016/ j.chom.2016.07.004

Bleyzac, N., Goutelle, S., Bourguignon, L., \& Tod, M. (2020). Azithromycin for COVID-19: More Than Just an mendukung penggunaan ivermectin pada pasien-pasien dengan infeksi coronavirus. Saat ini, lebih dari 50 penelitian sedang berlangsung membandingkan efektivitas ivermectin dengan obat-obatan lainnya, diharapkan ke depannya penelitian ini dapat berjalan dengan baik dan memberikan wawasan baru bagi kita semua.

\section{Konflik Kepentingan}

Tidak ada potensi konflik kepentingan yang dilaporkan oleh penulis.

Antimicrobial? Clinical Drug Investigation, 40(8), 683-686. doi: 10.1007/s40261-020-00933-3

Caly, L., Druce, J. D., Catton, M. G., Jans, D. A., \& Wagsta, K. M. (2020). The FDA-approved drug ivermectin inhibits the replication of SARS-CoV-2 in vitro. Antiviral Research, 178(January), 104787. doi: 10.1016/j.antiviral.2020.104787

Canga, A. G., Prieto, A. M. S., Diez Liébana, M. J., Martínez, N. F., Sierra Vega, M., \& García Vieitez, J. J. (2008). The pharmacokinetics and interactions of ivermectin in humans - A mini-review. AAPS Journal, 10(1), 42-46. doi: 10.1208/s12248-007-9000-9

Cascella, M., Rajnik, M., Cuomo, A., Dulebohn, S. C., \& Napoli, R. D. (2020). Features, Evaluation, and Treatment of Coronavirus. StatPearls [Internet]. Retrieve from : https://www.ncbi.nlm.nih.gov/books/NBK554776/

Chowdhury, A. T. M. M., Shahbaz, M., Karim, M. R., Islam, J., Guo, D., \& He, S. (2020). A Randomized Trial of IvermectinDoxycycline and Hydroxychloroquine-Azithromycin therapy on COVID19 patients. Research Square, 1-19. doi: 10.21203/rs.3.rs-38896/v1

Chu, D. K., Kim, L. H.-Y., Young, P. J., Zamiri, N., Almenawer, S. A., Roman, J., Alhazzani, W. ( 2018). Mortality and morbidity in acutely ill adults treated with liberal versus conservative oxygen therapy (IOTA): a systematic review and metaanalysis. Lancet, 391(10131):1693-1705. doi: 10.1016/S0140-6736(18)30479-3 
Crump, A., \& Omura, S. (2011). Ivermectin, "Wonder drug" from Japan: The human use perspective. Proceedings of the Japan Academy Series B: Physical and Biological Sciences, $87(2), 13-28$. doi: $10.2183 /$ pjab.87.13

Delvecchio, R., Higa, L. M., Pezzuto, P., Valadão, A. L., Garcez, P. P., Monteiro, F. L., et al. (2016). Chloroquine, an Endocytosis Blocking Agent, Inhibits Zika Virus Infection in Different Cell Models. Viruses, 8(12): 322. doi: 10.3390/v8120322

Donde, O. O., Atoni, E., Muia, A. W., \& Yilla, P. T. (2021). COVID-19 pandemic: Water, sanitation and hygiene (WASH) as a critical control measure remains a major challenge in lowincome countries. Water Res, 191: 116793. doi: 10.1016/j.watres.2020.116793.

Elkholy, K. O., Hegazy, O., Erdinc, B., \& Abowali, H. (2020). Ivermectin: A Closer Look at a Potential Remedy. Cureus, 12(9). doi:10.7759/cureus.10378

Farias, K. J., Machado, P. R., de Almeida Junior, R. F., de Aquino, A A., \& da Fonseca, A. B. (2014). Chloroquine interferes with dengue-2 virus replication in U937 cells. Microbiol. Immunol, 318-326. doi: 10.1111/1348-0421.12154

Gorial, F. I., Mashhadani, S., Sayaly, H. M., Dakhil, B. D. AlMashhadani, M. M., Aljabory, A. M., Abbas, H. M., Ghanim, M., \& Rasheed, J. I. (2020). Effectiveness of ivermectin as add-on therapy in COVID-19 management (pilot trial). MedRxiv, 2(December 2019), 2-13. doi: 10.1101/2020.07.07.20145979

Gupta, D., Sahoo, A. K., \& Singh, A. (2020). Ivermectin: potential candidate for the treatment of Covid 19. Brazilian Journal of Infectious Diseases, 24(4), 369-371. doi: 10.1016/j.bjid.2020.06.002

Hashim, H. A., Maulood, M. F., Rasheed, A. M., Fatak, D. F., Kabah, K. K., \& Abdulamir, A. S. (2020). Controlled randomized clinical trial on using Ivermectin with Doxycycline for treating COVID-19 patients in Baghdad, Iraq. MedRxiv, 48, 2020.10.26.20219345.

Heidary, F., \& Gharebaghi, R. (2020). Ivermectin: a systematic review from antiviral effects to COVID-19 complementary regimen. Journal of Antibiotics, 73(9), 593-602.

Ibáñez, S., Martínez, O., Valenzuela, F., Silva, F., \& Valenzuela, O. (2020). Hydroxychloroquine and chloroquine in COVID-19: should they be used as standard therapy? Clinical Rheumatology, 39(8), 2461-2465. doi: 10.1007/s10067020-05202-4

Jans, D. A., \& Wagstaff, K. M. (2020). The broad spectrum hostdirected agent ivermectin as an antiviral for SARS-CoV-2 ? Biochemical and Biophysical Research Communications, January. doi: 10.1016/j.bbrc.2020.10.042

Kahn, M., Santhosh, S., Tiwari, M., Rao, L., \& Parida, M. (2010). Assessment of In Vitro Prophylactic and Therapeutic Efficacy of Chloroquine Against Chikungunya Virus in Vero Cells. Journal of Medical Virology, 82, 817-824. doi: 10.1128/microbiolspec. El10-0017-2016

Khan, S. I., Khan, S. I., Debnathc, C. R., Nath, P. N., Mahtab, M. Al, Nabeka, H., Matsuda, S., \& Akbar, S. M. F. (2020). Ivermectin Treatment May Improve the Prognosis of Patients With COVID-19. Arch Bronconeumol, 56(12), 828-830. doi : 10.1016/j.arbres.2020.08.007

Khuroo, M. S. (2020). Chloroquine and hydroxychloroquine in coronavirus disease 2019 (COVID-19). Facts, fiction and the hype: a critical appraisal. Int J Antimicrob Agents, 56(3): 106101. doi: 10.1016/j.ijantimicag.2020.106101

Li, H., Liu, S.-M., Yu, X.-H., \& Tang, C.-K. (2020). Coronavirus disease 2019 (COVID-19): current status and future perspectives. Int J Antimicrob Agents, 55(5): 105951. doi: 10.1016/j.jjantimicag. 2020.105951

Matthay, M. A., \& Thompson, T. B. (2020). Dexamethasone in hospitalized patients with COVID-19: addressing uncertainties. The Lancet, 1170 - 1172. doi: 10.1016/S2213-2600(20)30503-8

Miranda, C., Silva, V., Capita, R., Alonso-Calleja, C., Igrejas, G., \& Poeta, P. (2020). Implications of antibiotics use during the COVID-19 pandemic: Present and future. Journal of Antimicrobial Chemotherapy, 75(12), 3413-3416. doi: 10.1093/ jac/dkaa350

Rajter, J. C., Sherman, M. S., Fatteh, N., Vogel, F., Sacks, J., \& Rajter, J. J. (2021). Use of Ivermectin Is Associated With Lower Mortality in Hospitalized Patients With Coronavirus Disease 2019: The Ivermectin in COVID Nineteen Study. Chest, 159(1), 85-92. doi: 10.1016/j.chest.2020.10.009

Shenoy, N., Luchtel, R., \& Gulani, P. (2020). Considerations for target oxygen saturation in COVID-19 patients: are we under-shooting? BMC Med, 18: 260. doi: 10.1186/s12916020-01735-2

Sieswerda, E., Boer, M. G. J. De, Bonten, M. M. J., Boersma, W. G., Jonkers, E., Aleva, R. et al. (2020). Recommendations for antibacterial therapy in adults with COVID-19 e an evidence based guideline. Clin Microbiol Infect, 27(January), 61-66. doi: 10.1016/j.cmi.2020.09.041

Singh, A. K., Majumday, S., Singh, R., \& Anoop, M. (2020). Role of corticosteroid in the management of COVID-19: A systemic review and a Clinician's perspective. Diabetes Metab Syndr, 14(5): 971-978. doi: 10.1016/j.dsx.2020.06.054

Singhai, T. (2020). A Review of Coronavirus Disease-2019 (COVID-19). Indian J Pediatr, 281-286. doi: 10.1007/s12098-020-03263-6

Wang, J.-W., Yang, L., Luo, R.-G., \& Xu, J.-F. (2020). Corticosteroid administration for viral pneumonia: COVID-19 and beyond. Clin Microbiol Infect, 26(9): 1171-1177. doi: 10.1016/j.cmi.2020.06.020

Weiss, S. R., \& Martin, S. N. (2005). Coronavirus Pathogenesis and the Emerging Pathogen Severe Acute Respiratory Syndrome Coronavirus. Microbiol Mol Biol Rev, 635-664. doi: 10.1128/MMBR.69.4.635-664.2005

Wu, C., Chen, X., Cai, Y., Xia, J., Zhou, X., Xu, S., Huang, H., et al. (2020). Risk Factors Associated With Acute Respiratory Distress Syndrome and Death in Patients With Coronavirus Disease 2019 Pneumonia in Wuhan, China. JAMA Intern Med, 180(7), 1-11. doi: 10.1001/jamainternmed.2020.0994

Yavuz, S. Ş., \& Ünal, S. (2020). Antiviral treatment of COVID-19. Turk J Med Sci, 50(3): 611-619. doi: 10.3906/sag-2004145. 